\title{
Potential proapoptotic phytochemical agents for the treatment and prevention of colorectal cancer (Review)
}

\author{
KANWAL AHMED $^{1,2}$, SYED FAISAL ZAIDI ${ }^{1,2}$, ZHENG-GUO CUI ${ }^{3,4}$, \\ DEJUN ZHOU ${ }^{4}$, SHEIKH ABDUL SAEED ${ }^{1,2}$ and HIDEKUNI INADERA ${ }^{3}$ \\ ${ }^{1}$ Department of Basic Medical Sciences, College of Medicine, King Saud Bin Abdulaziz University for Health Sciences; \\ ${ }^{2}$ King Abdullah International Medical Research Center, Jeddah 21423, Saudi Arabia; ${ }^{3}$ Department of Public Health, \\ Graduate School of Medicine and Pharmaceutical Sciences, University of Toyama, Toyama 930-0194, Japan; \\ ${ }^{4}$ Graduate School of Medicine, Henan Polytechnic University, Jiaozuo, Henan 454000, P.R. China
}

Received October 15, 2018; Accepted March 11, 2019

DOI: $10.3892 /$ ol.2019.10349

\begin{abstract}
Colorectal cancer (CRC) is one of the leading causes of mortality among men and women. Chemo-resistance, adverse effects and disease recurrence are major challenges in the development of effective cancer therapeutics. Substantial literature on this subject highlights that populations consuming diets rich in fibers, fruits and vegetables have a significantly reduced incidence rate of $\mathrm{CRC}$. This chemo-preventive effect is primarily associated with the presence of phytochemicals in the dietary components. Plant-derived chemical agents act as a prominent source of novel compounds for drug discovery. Phytochemicals have been the focus of an increasing number of studies due to their ability to modulate carcinogenic processes through the alteration of multiple cancer cell survival pathways. Despite promising results from experimental studies, only a limited number of phytochemicals have entered into clinical trials. The purpose of the current review is to compile previously published pre-clinical and clinical evidence of phytochemicals in cases of CRC. A PubMed, Google Scholar and Science Direct search was performed for relevant articles published between 2008-2018 using the following key terms: 'Phytochemicals with colorectal cancers', 'apoptosis', 'cell cycle', 'reactive oxygen species' and 'clinical anticancer activities'. The present review may aid in identifying the most investigated phytochemicals in CRC cells, and due to the limited number of studies that make it from the laboratory bench to clinical trial stage, may provide a novel foundation for future research.
\end{abstract}

Correspondence to: Dr Kanwal Ahmed, Department of Basic Medical Sciences, College of Medicine, King Saud Bin Abdulaziz University of Health Sciences, Jeddah 21423, Saudi Arabia

E-mail:kanwalahd@gmail.com

Dr Zheng-Guo Cui, Department of Public Health, Graduate School of Medicine and Pharmaceutical Sciences, University of Toyama, 2360 Sugitani, Toyama 930-0194, Japan

E-mail: sai@med.u-toyama.ac.jp

Key words: colorectal cancer, apoptosis, phytochemicals, reactive oxygen species, cell cycle arrest

\section{Contents}

1. Introduction

2. Literature review method

3. Apoptosis-inducing phytochemicals in CRC

4. Carotenoids

5. Phenolic compounds

6. Alkaloids

7. Evidence from clinical trials

8. Conclusions and future directions

\section{Introduction}

Colorectal cancer (CRC) is the third most common cancer diagnosed in men and women and is the fourth leading cause of cancer-associated mortality worldwide (1). In 2018, $>30,000$ CRC-associated mortalities were reported in the USA (2). According to the World Health Organization, in 2008, 1.2 million new CRC cases were reported globally (3). Annually $>0.6$ million patients succumb due to CRC (4), and a family history of CRC or chronic inflammatory bowel disease is a contributing factor for disease progression (5). Additionally, a sedentary lifestyle, low physical activity and unhealthy dietary patterns, including diets with low fiber and a high content of red meat or fat, cigarette smoking and alcohol abuse, are the major causes of CRC development. The majority of CRC cases are diagnosed at the advanced stages of disease, which makes curative treatment impossible (6).

Understanding the developmental pathways in tumor cells that promote the growth and metastasis of tumors is important in order to identify the molecular targets of cancer therapeutics. The majority of CRC cases occur as a result of genetic and epigenetic modifications (7-9). Studies investigating human cancer, including $\mathrm{CRC}$, have demonstrated a central role of p53 in tumor suppression (10). Almost 50\% of CRC cases are reported to have a mutation in p53 (9), which promotes cell proliferation, invasion, metastasis and resistance to a variety of anticancer drugs, such as 5 fluorouracil $(11,12)$. Mutations in the KRAS, BRAF and neuroblastoma RAS viral oncogene genes have also been reported in CRC (13). Additionally, mutations of the adenomatous polyposis coli gene in CRC 
promotes the dysfunction of $\beta$-catenin and activates the Wnt pathway, which is an activator of the key cell cycle regulatory genes cyclin D1 and c-Myc, which provide suitable conditions for cellular proliferation (13). In CRC, the activation of NF- $x \mathrm{~B}$ upregulates a number of genes responsible for the generation of pro-inflammatory mediators and cytokines, which are essential for CRC cell propagation (14). Additionally, the $\mathrm{PI} 3 \mathrm{~K} / \mathrm{Akt}$ pathway promotes tumor proliferation via inhibition of apoptosis and stimulation of the cell cycle (15).

High levels of reactive oxygen species (ROS) have been detected in almost all types of cancer and been demonstrated to potentiate numerous aspects of tumor development and progression. Under physiological conditions, the intracellular ROS levels are not high enough to induce cell damage. However, any imbalance in the redox status of the cell results in oxidative stress, which exerts an important function in the initiation, promotion and progression of carcinogenesis (16). Physical agents, chemical agents, inflammation and infection potentiate oxidative stress, which directly damages DNA and promotes tumorigenesis (17). Under mild oxidative stress, wild-type p53 is reported to induce the expression of antioxidant enzymes, and stimulates cell repair and survival mechanisms $(18,19)$. However, upon acute oxidative stress, p53 reduces the expression of detoxifying enzymes and stimulates apoptosis (20). By contrast, mutated p53 exhibited in cancer cells cannot induce the expression of antioxidant enzymes to detoxify higher levels of ROS, whereas it upregulates cell proliferative gene expression, which promotes the propagation of DNA damage (21).

Apoptosis is a tightly regulated mechanism of cell death and a stress response to toxic stimuli that is required to maintain intestinal epithelial cell homeostasis. Spontaneous apoptosis continuously occurs in the normal, unstressed intestine and stress-induced apoptosis occurs following genotoxic insult, including exposure to DNA-damaging agents. In cancer cells, dysregulation of the apoptotic process results in disturbance of tissue homeostasis, which then results in uncontrolled proliferation of cells (22). Caspases function as initiators and executors of apoptosis. Initiator caspases, including caspase- 8 and -9 , which are involved in the extrinsic and intrinsic apoptotic pathways, activate effector caspases, including caspase-3 and -7 , which cleave several proteins, including poly(ADP ribose) polymerase-1 (PARP-1) in cells $(23,24)$. PARP-1 is a nuclear enzyme involved in DNA repair, DNA stability and transcriptional regulation. PARP-1 cleavage prevents recruitment of enzymes to the site of DNA damage and is considered to be a hallmark of apoptosis (Fig. 1) (25).

The endoplasmic reticulum (ER) is responsible for the synthesis, folding and maturation of proteins (26). Conditions that result in ER stress can activate cell protective mechanisms; however, if the stress is excessive or prolonged then it will eliminate cells via the intrinsic apoptosis pathway (26). This switch between pro-survival and pro-apoptotic pathways is due to the induction of a transcriptional factor C/EBP homologous protein (CHOP) (27), which has been reported to downregulate the anti-apoptotic protein $\mathrm{Bcl}-2$ (28). Additionally, ER stress increases intracellular calcium $\left(\mathrm{Ca}^{2+}\right)$ levels, which activates calpain-induced cleavage of anti-apoptotic B-cell lymphoma-extra large (Bcl-xl) and increases caspase-12 activity, which then activates caspase- 9 independent of apoptotic protease activating factor 1 (Apaf-1), followed by the activation of caspase-3 (Fig. 1) $(29,30)$.

The activation of apoptosis is an important mechanism for CRC prevention and treatment (31-33). Dietary phytochemicals are known to prevent the initiation of carcinogenesis via the induction of antioxidant enzymes and block the progression of carcinogenic cells via the induction of apoptosis and cell cycle arrest $(34,35)$. Almost 50\% the approved anticancer drugs are derived from natural products or their derivatives $(36,37)$. To establish novel compounds that can be utilized in combined therapy to potentiate the effect of chemotherapeutic drugs, a number of studies have been performed to identify agents present in diet or herbs that interfere with proliferative cell signaling pathways (34-38). The aim of the present study was to compile available literature published between 2008-2018 regarding the mechanisms of apoptosis induced by phytochemicals in CRC cells in preclinical and clinical settings. This may assist in providing a solid foundation for future research options in this field.

\section{Literature review method}

The present review is based on a literature search of PubMed (ncbi.nlm.nih.gov/pubmed/), Google Scholar (scholar.google. $\mathrm{com} /$ ) and Science Direct (sciencedirect.com/) to identify relevant studies published between 2008-2018. The search was performed with the following key terms: 'Phytochemicals with colorectal cancers', 'apoptosis', 'reactive oxygen species (ROS)' and 'clinical anticancer activities'. Only studies investigating the effects of phytochemicals on patients with CRC in preclinical and clinical trials were included in the present review.

\section{Apoptosis-inducing phytochemicals in CRC}

Phytochemicals are a non-nutritive group of compounds naturally present in fruits, vegetables, spices, grains and herbs, which have health promoting and disease preventing characteristics (39). In preclinical and clinical studies of different types of tumor, the consumption of fruits and vegetables has been reported to exert beneficial health effects $(39,40)$. CRC is strongly associated with dietary factors and the association of phytochemicals with CRC prevention has been reported in several studies (41-43). Numerous phytochemicals exhibit chemo-preventive effects in CRC due to their antioxidative and ROS scavenging activities. However, various phytochemicals are also known to induce apoptosis by promoting ROS generation (44-62). Table I details a list of ROS-inducing phytochemicals in CRC.

The induction of apoptosis and inhibition of tumor cell proliferation by cell cycle arrest are markers for the evaluation of phytochemical anticancer activities. Table II details a list of phytochemicals that can induce CRC cell cycle arrest at different phases of the cell cycle $(45,48,51,54,55$, 57,59,60,63-84). Phytochemicals are classified according to their chemical structure, for example, carotenoids, alkaloids and phenolic compounds such as flavonoids, phenolic acid, stilbenes (resveratrol), curcuminoids, tannins and cumarins (85). The following sections discuss the apoptotic mechanisms of different classes in detail. 


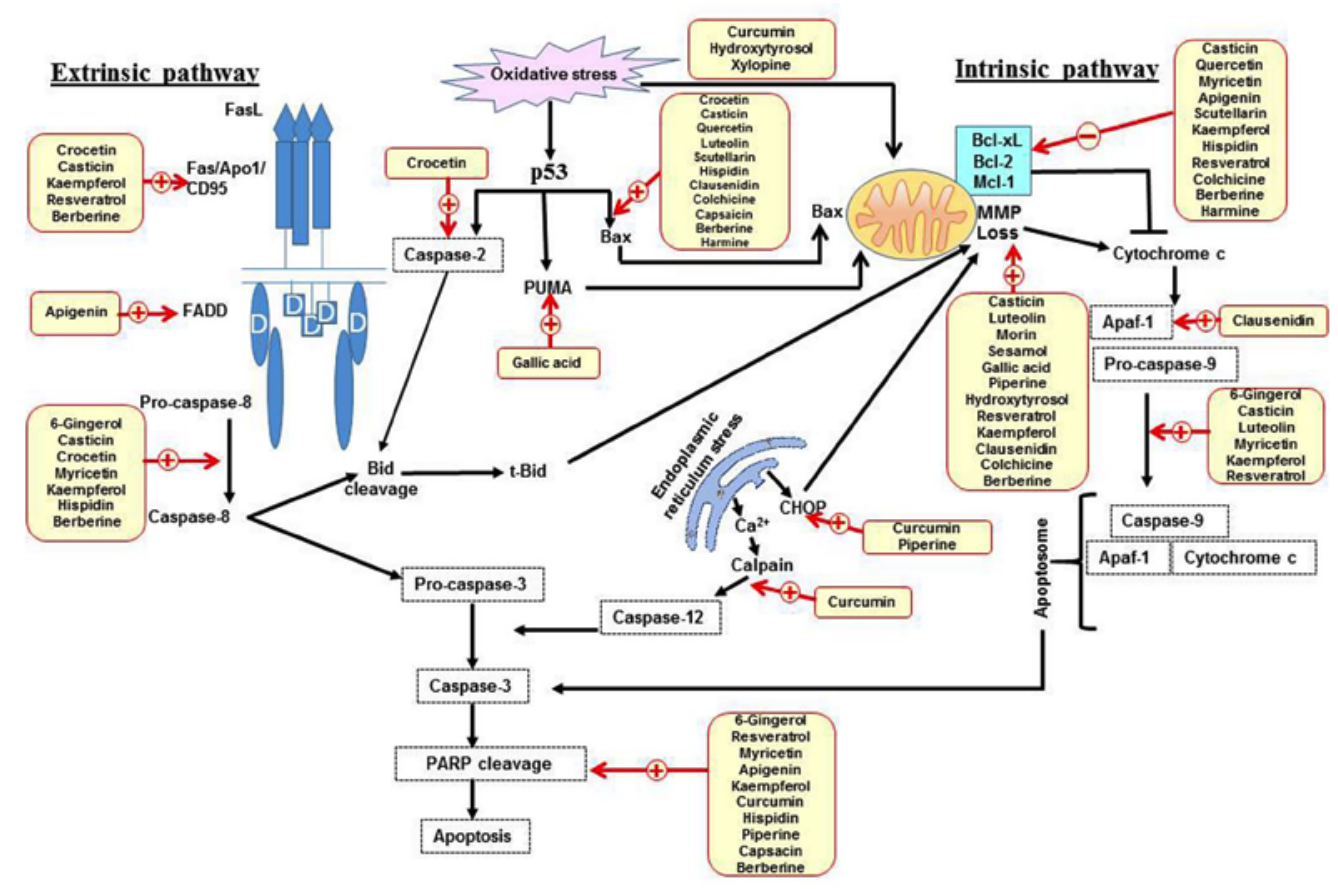

Figure 1. Signaling pathways of apoptosis and molecular targets of phytochemicals. Depending on the cell type and status of p53, phytochemicals can induce apoptosis by regulating targets of the extrinsic and intrinsic apoptosis pathways shown in black arrows. Red arrows indicate effects of phytochemicals on different apoptosis targets. Phytochemicals with activating and inhibiting activities are shown with + and - symbols, respectively. FasL, Fas ligand; FADD, Fas-associated death domain; PUMA, p53 upregulated modulator of apoptosis; PARP, poly(ADP ribose) polymerase-1; CHOP, C/EBP homologous protein; Bcl-xL, B-cell lymphoma-extra large; Mcl-1, myeloid cell leukemia sequence-1; Apaf-1, apoptotic protease activating factor 1.

\section{Carotenoids}

Carotenoids are colored lipid soluble pigments present in plants, fungi, bacteria and algae, and also have been identified in numerous foods, including fruit, vegetables and fish. Carotenoids are responsible for providing bright coloration to plants and animal. There are $>600$ carotenoids with natural structural variations, which are divided into lycopenes, $\beta$-carotenes, luteins and zeaxanthins (86).

Carotenoids are the most characteristic and important components present in saffron (Crocus sativus L.) stigmas. In ancient times, the Arabs, Indians and Chinese used carotenoids for the treatment of various diseases, including cancer. Crocetin is the most potent carotenoid in saffron $(86,87)$. Crocetin can induce different apoptotic mechanisms in colon cancer cells with varying p53 statuses. The presence of wild-type p53 in HCT 116 cells trans-activates Bax along with upregulation of p53-induced death domain protein, which cleaves and activates Bid via caspase-2 (88). However, in functional p53-impaired cells (HCT 116 p53-/-), augmentation of the p53-paralogue p73 was observed, which upregulates Fas to cleave Bid through the Fas-associated death domain (FADD)-caspase-8-pathway (88).

\section{Phenolic compounds}

6-Gingerol. Ginger contains numerous phenolic compounds, including 6-gingerol, 6-shagol, 6-paradol and zingerone (89). Among these compounds, 6-gingerol has been extensively investigated for its cytotoxic effects in various types of cancer, including colon cancer $(83,84)$. 6-gingerol inhibits the proliferation of SW480 colon cancer cells by arresting them at the $\mathrm{G}_{2} / \mathrm{M}$ phase and induces apoptosis via activation of caspase- 8 , $-9,-3$ and -7 and PARP cleavage (75).

Flavonoids. Flavonoids are one of the largest groups of naturally-occurring phenols, including flavones, flavanols, isoflavones, flavonols, flavanones and flavanonols (90). Flavonoids are present in fruits, vegetables, grains, bark, roots, stems, flowers, tea and wine. Along with carotenoids, they are responsible for the vivid colors in fruits and vegetables (91). Flavonoids are known for their anti-oxidative, anti-inflammatory, anti-mutagenic and anti-carcinogenic properties (91).

Casticin, a flavonoid derived from the natural plant Fructus Viticis, has been demonstrated to exert its apoptotic effect in colo 201 cells by arresting cells at the $\mathrm{G}_{2} / \mathrm{M}$ phase. Casticin increases ROS production, decreases the expression of matrix metalloproteinases, increases the release of cytochrome $c$ from the mitochondria and triggers the activation of caspase-8, -9 and -3 . Additionally, increases in tumor necrosis factor (TNF)-related apoptosis-inducing ligand (TRAIL), Fas, Fas ligand (FasL) and FADD have been observed following treatment with casticin (55). Furthermore, casticin upregulates the pro-apoptotic proteins $\mathrm{Bax}, \mathrm{BH} 3$ interacting domain death agonist (Bid) and Bcl-2 antagonist/killer, and downregulates Bcl-2 and Bcl-xl, which induces apoptosis via the extrinsic and intrinsic apoptotic pathways (55). 


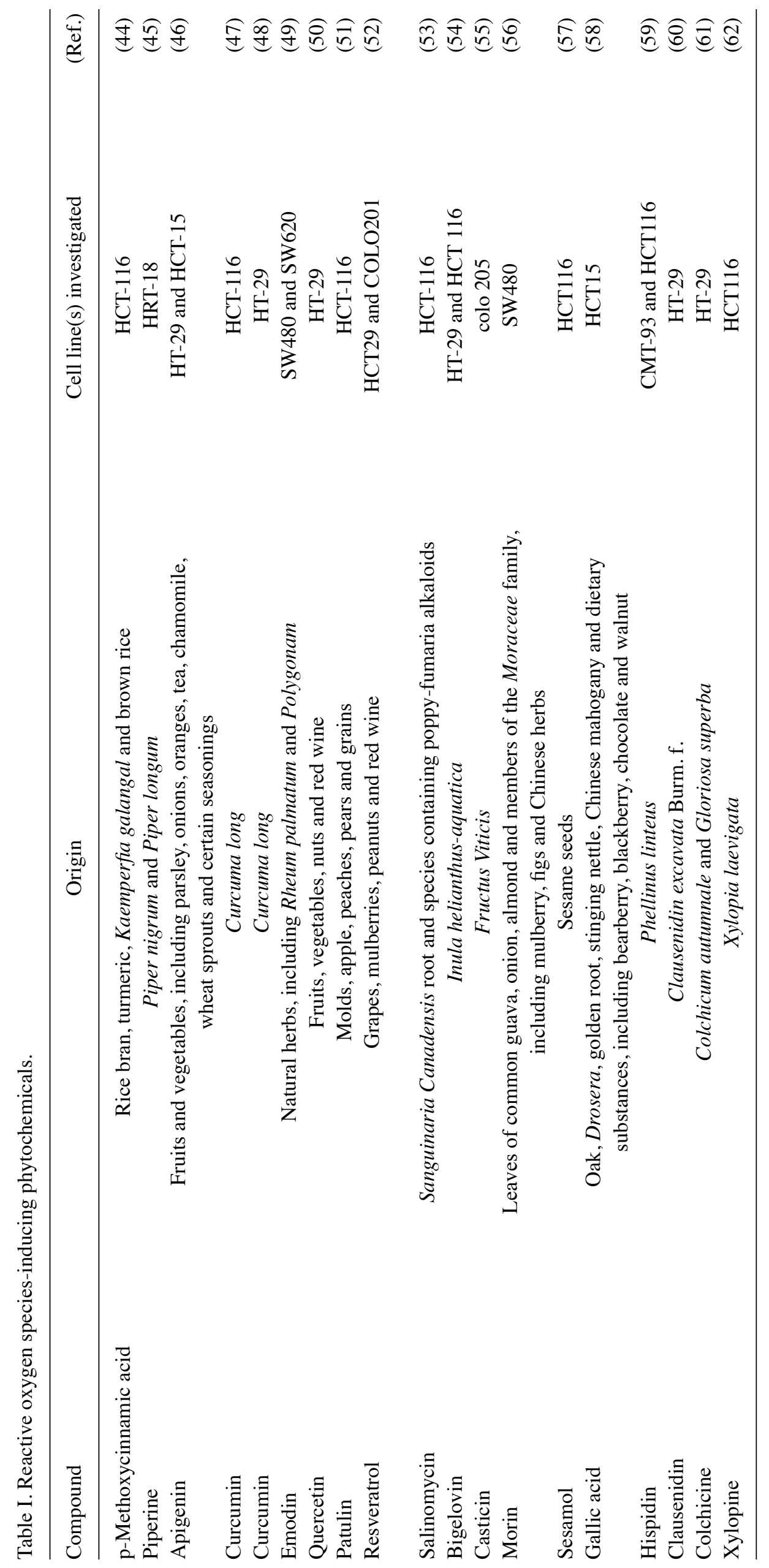


Table II. Cell cycle-arresting phytochemicals.

\begin{tabular}{|c|c|c|c|c|}
\hline Compound & Origin & $\begin{array}{l}\text { Cell line(s) } \\
\text { investigated }\end{array}$ & $\begin{array}{l}\text { Cell cycle } \\
\text { phase }(s)\end{array}$ & (Ref.) \\
\hline Artocarpin & Artocarpus heterophyllus & HT-29 & $\mathrm{G}_{1}$ & (63) \\
\hline Silibinin & Silybum marianum & LoVo & $\mathrm{G}_{1}$ and $\mathrm{G}_{2} / \mathrm{M}$ & $(64)$ \\
\hline Piperine & Piper nigrum and Piper longum & HRT-18 & $\mathrm{G}_{0} / \mathrm{G}_{1}$ & $(45)$ \\
\hline Piperine & Piper nigrum and Piper longum & HT-29 & $\mathrm{G}_{1}$ & $(65)$ \\
\hline Vicenin-2 & Ocimum sanctum Linn and Moringa oleifera & HT-29 & $\mathrm{G}_{2} / \mathrm{M}$ & $(66)$ \\
\hline Curcumin & Curcuma longa & COLO & $\mathrm{G}_{0} / \mathrm{G}_{1}$ & $(67)$ \\
\hline Curcumin & Curcuma longa & 320DM & $\mathrm{S}$ & $(68)$ \\
\hline Curcumin & Curcuma longa & HT-29 & $\mathrm{G}_{2} / \mathrm{M}$ & $(48)$ \\
\hline Patulin & Molds, apple, peaches, pears and grain & HCT116 & $\mathrm{G}_{2} / \mathrm{M}$ & $(51)$ \\
\hline Resveratrol & Grapes, mulberries, peanuts and red wine & HCT-116 and $\mathrm{Caco}_{2}$ & $\mathrm{G}_{1} / \mathrm{S}$ & $(69)$ \\
\hline Bigelovin & Inula helianthus-aquatica & HT-29 and HCT 116 & $\mathrm{G}_{2} / \mathrm{M}$ & $(54)$ \\
\hline Plumbagin & Plumbago zeylinica & HCT116 & $\mathrm{G}_{1}$ & $(70)$ \\
\hline Cucurbitacin-I & Cucurbitaceae species & SW480 & $\mathrm{G}_{2} / \mathrm{M}$ & (71) \\
\hline Crocin & Crocus sativus L. (Saffron) & HCT116 wild-type & $\mathrm{G}_{0} / \mathrm{G}_{1}$ & $(72)$ \\
\hline Crocin & Crocus sativus L. (Saffron) & НCT116 p53(-/-) & $\mathrm{G}_{2} / \mathrm{M}$ & $(72)$ \\
\hline Crocetin & Crocus sativus L. (Saffron) & SW480 & $\mathrm{S}$ & $(73)$ \\
\hline Ginkgetin & Ginkgo biloba and Dioon & HCT116 & $\mathrm{G}_{2} / \mathrm{M}$ & $(74)$ \\
\hline Casticin & Fructus Viticis & colo 205 & $\mathrm{G}_{2} / \mathrm{M}$ & $(55)$ \\
\hline 6-Gingerol & Ginger & SW480 & $\mathrm{G}_{2} / \mathrm{M}$ & $(75)$ \\
\hline Quercetin & Fruits, vegetables, nuts and red wine & HT-29 & $\mathrm{G}_{0} / \mathrm{G}_{1}$ & $(76)$ \\
\hline Kaempferol & Fruits and vegetables & HT-29 & $\mathrm{G}_{1}$ and $\mathrm{G}_{2} / \mathrm{M}$ & $(77)$ \\
\hline Sesamol & Sesame seeds & HCT116 & $\mathrm{S}$ & $(57)$ \\
\hline Hispidin & Phellinus linteus & CMT-93 and HCT116 & Sub $G_{1}$ & $(59)$ \\
\hline Hydroxytyrosol & Virgin olive oil & $\mathrm{Caco}_{2}$ and $\mathrm{HT} 29$ & $\mathrm{G}_{1}$ & (78) \\
\hline Hydroxyphenylpropionic & Virgin olive oil & $\mathrm{Caco}_{2}$ and $\mathrm{HT} 29$ & $\mathrm{G}_{2} / \mathrm{M}$ & $(78)$ \\
\hline Phenylacetic & Virgin olive oil & $\mathrm{Caco}_{2}$ & $\mathrm{G}_{2} / \mathrm{M}$ & $(78)$ \\
\hline Catechol & Virgin olive oil & $\mathrm{CacO}_{2}$ & $\mathrm{~S}$ & (78) \\
\hline Clausenidin & Clausenidin excavata Burm. $\mathrm{f}$. & HT29 & $\mathrm{G}_{0} / \mathrm{G}_{1}$ & $(60)$ \\
\hline Xylopine & Xylopia laevigata & HCT116 & $\mathrm{G}_{2} / \mathrm{M}$ & $(62)$ \\
\hline Capsaicin & Red hot pepper & НCТ116 & $\mathrm{G}_{0} / \mathrm{G}_{1}$ & $(79)$ \\
\hline Capsaicin & Red hot pepper & LoVo & $\mathrm{G}_{0} / \mathrm{G}_{1}$ & $(80)$ \\
\hline Berberine & Berberis and Coptis & SW480 & $\mathrm{G}_{0} / \mathrm{G}_{1}$ & $(81)$ \\
\hline Berberine & Berberis and Coptis & HCT-8 & $\mathrm{S}$ & $(82)$ \\
\hline Berberine & Berberis and Coptis & LoVo & $\mathrm{G}_{2} / \mathrm{M}$ & $(83)$ \\
\hline Harmine & Peganum Harmala & SW620 & $\mathrm{S}$ and $\mathrm{G}_{2} / \mathrm{M}$ & $(84)$ \\
\hline
\end{tabular}

Quercetin is a major dietary flavonoid that has been identified in a wide range of fruits, vegetables and beverages, including tea and wine. Quercetin is known for its antioxidant, anti-inflammatory and anti-proliferative properties (50). In HT-29 colon cancer cells quercetin treatment decreases cell viability, arrests the cell cycle at the $\mathrm{G}_{1}$ phase and induces apoptosis $(76,92)$. Quercetin inhibits the PI3K-mediated cell survival signaling pathway via phosphorylation of its downstream target Akt (92). Additionally, quercetin decreases the expression of COP9 signalosome subunit 6 (CSN6), a subunit of the constitutive photomorphogenesis 9 multiprotein complex (76). Akt is a known regulator of CSN6, which promotes carcinogenesis by stabilizing the viral oncogene homolog Myc (76). Furthermore, quercetin-treatment targets
CSN6 genes to induce apoptosis, as it downregulates Myc and Bcl-2 expression, and increases the expression of $\mathrm{p} 53$ and Bax $(76,92)$. Quercetin has also been demonstrated to suppress the $\mathrm{Wnt} / \beta$-catenin and NF- $x \mathrm{~B}$ pathways in CRC cells $(93,94)$. Additionally, treatment of HT-29 cells with quercetin upregulates AMP-activated protein kinase, a physiological cellular energy sensor, which markedly suppresses cell proliferation (92).

Luteolin (3',4',5,7-tetrahydroxyflavone) is a common flavonoid that exists in numerous types of plants including fruits, vegetables and medicinal herbs (95). Plants rich in luteolin have been used in Chinese traditional medicine for the treatment of various diseases, including hypertension, inflammatory disorders and cancer (95). Luteolin decreases the cell 
viability of HT-29 cells without affecting normal colon cells and it has been observed to induce apoptosis of HT-29 cells by activating the mitochondria-mediated caspase pathway (96). Treatment of HT-29 cells with luteolin results in a loss of the mitochondrial membrane potential, an increase in mitochondrial $\mathrm{Ca}^{2+}$ level, upregulation of Bax, downregulation of Bcl-2, release of cytochrome $c$ from the mitochondria to the cytosol and an increase in the levels of the active forms of caspase- 9 and caspase-3 (96).

Morin is a flavonoid primarily identified in the leaves of common guava, onion and almonds, and in members of the Moraceae family, including mulberry, figs and Chinese herbs. The pro-oxidative effect of morin in SW480 cells results in a disturbance of the mitochondrial function, which results in the activation of the intrinsic and the extrinsic apoptosis pathways (56). Additionally, morin induces a significant reduction in glucose transporter-1 expression, which results in a decline in cellular glucose uptake, resulting in an impaired mitochondrial function, which further sensitizes cells to undergo apoptosis via the intrinsic apoptosis pathway (56).

Scutellarin is a flavonoid isolated from a medicinal herb Scutellaria barbata D. Don. Scutellarin is widely used in Korea and South China to treat cardiovascular, neurological and inflammatory diseases (97). In colon cancer cells, scutellarin downregulates the anti-apoptotic protein Bcl-2 and induces apoptosis by activating $\mathrm{p} 53$, which upregulates Bax to activate caspase 3 via the mitochondrial pathway (97).

Myricetin is a flavonoid present in fruits, vegetables, tea, berries and medicinal plants (98). Myricetin has been reported to exhibit anticancer activity in the colon cancer HCT-115 cells via activation of nucleoside diphosphate kinase, which has been reported to induce apoptosis and inhibit metastasis in various types of cancer, such as hepatocellular carcinoma and pancreatic cancer $(99,100)$. Additionally, myricetin activates caspase-3,- 8 and -9 , and PARP, and downregulates the anti-apoptotic $\mathrm{Bcl}-2$ protein to induce apoptosis in colon cancer cells (98).

Apigenin is a common flavonoid present in numerous plants, fruits and vegetables. The primary source of its consumption is chamomile tea, which is prepared from dried flowers of Matricaria chamomilla (101). Apigenin has been reported to exert anti-proliferative and anti-metastatic effects in a variety of CRC cell lines, such as those for lung cancer and osteosarcoma $(102,103)$. Additionally, apigenin has been demonstarted to inhibit the Wnt/ $\beta$-catenin signaling pathway $(101,103)$ and suppress the phosphorylation of STAT3 (104), which in turn results in the downregulation of the anti-apoptotic proteins Bcl-xl and myeloid cell leukemia sequence-1 (Mcl-1), which stimulates the cleavage of PARP and the apoptosis of colon cancer cells (104). Furthermore, an in vivo study revealed that apigenin increases the apoptotic index of SW480 colon cancer cells via an upregulation of FADD (101).

Kaempferol is a flavonol present in fruits and vegetables, including apples, onions, and green and black tea (105). A high intake of kaempferol has been reported to reduce the risk of colon cancer (105). Kaempferol induces apoptosis of HT-29 colon cancer cells via activation of the extrinsic and intrinsic apoptosis pathways. Kaempferol initiates the extrinsic apoptosis pathway by increasing the level of FasL, which binds with the Fas receptor and activates caspase- 8 . Caspase- 8 then cleaves Bid and interacts with the intrinsic apoptosis pathway via translocation of $\mathrm{t}$-Bid to the mitochondria, as evident by the release of cytochrome $c$, activation of caspase-9, -7 and -3 , and PARP cleavage (106). Additionally, kaempferol decreases the expression of the anti-apoptotic protein $\mathrm{Bcl}-\mathrm{xl}$ and reduces Akt activity (106).

Curcuminoids. Curcumin, a derivative of turmeric (Curcuma longum), is a widely investigated phenolic compound that possesses potent anti-inflammatory, antioxidant and anticancer properties (107). It has previously been reported that curcumin induces apoptosis in human colon cancer HT29 cells via the calpain/caspase-12 apoptotic pathway (48). A previous study demonstrated that curcumin induces ROS generation in p53 mutated HT-29 cells, which results in cell cycle arrest and apoptosis via activation of the ROS-mediated mitochondrial pathway (47). Furthermore, curcumin induces caspase-3-mediated PARP cleavage in $\mathrm{p}^{+/+}$and $\mathrm{p} 53^{-1-}$ HCT116 cells, which indicates that the p53 status does not interfere with the ability of curcumin to induce apoptosis (47). In recent in vitro and in vivo studies, co-treatment of curcumin with TRAIL increased TRAIL-induced apoptosis via an upregulation of death receptor 4 and 5 (108). Additionally, in chemo-resistant CRC cells curcumin enhanced the potential of conventional chemotherapeutic drugs via inhibition of drug induced proliferative targets, including cyclin $\mathrm{D} 1, \mathrm{NF}-\varkappa \mathrm{B}$, PI3K and Src (109,110).

Sesamol. Sesamol is a phenolic compound present in sesame seeds that has been extensively investigated in different types of cancer, such as hepatocellular carcinoma and skin tumors $(111,112)$. However, to the best of our knowledge, only a single study has been performed with CRC cells (57). Sesamol acts as an antioxidant at lower concentrations, while at higher concentrations it exhibits pro-oxidant effects, which decrease the viability of colon cancer HCT116 cells via interruption of the cell cycle at the S-phase and induces apoptosis via mitochondrial dysfunction (57).

Phenolic acid. Gallic acid is a type of phenolic acid that is present in dietary substances, including blackberries, chocolate, walnuts, raspberries, clove, vinegar, wine, green tea and herbs, including oak, drosera, golden root, stinging nettle and Chinese mahogany $(58,113)$. Gallic acid is associated with oxidative stress and arrests HCT-15 cells at the sub $\mathrm{G}_{1}$ phase (58). Additionally, gallic acid has been reported to activate p53 upregulated modulator of apoptosis, which is a pro-apoptotic protein that potentiates the release of cytochrome $c$ from the mitochondria via disruption of the mitochondrial membrane potential (MMP), which demonstrates the involvement of the intrinsic apoptosis pathway (114).

Hispidin. Hispidin is a phenolic compound isolated from Phellinus linteus, a medicinal mushroom that is cultivated in Korea, Japan and China, and is well known for its antioxidant activity (59). Hispidin induces apoptosis and ROS generation in colon cancer cells (59). Additionally, hispidin increases the p53 level and promotes the expression of its downstream 
protein Bax, while decreasing the expression of the anti-apoptotic protein Bcl-2, which contributes to the intrinsic apoptosis pathway. Furthermore, increased expression of death receptor 3 and cleavage of caspase- 8 , caspase- 1 and PARP indicates the involvement of the extrinsic pathway in hispidin-induced apoptosis (59).

Hydroxytyrosol (HT). HT is an important phenolic compound present in virgin olive oil (77). HT is transformed into several metabolites, including phenylacetic (PA), phenylpropionic acid (PP), hydroxyphenylpropionic (HPP), dihydroxyphenylpropionic (diHPP) acids and catechol, via phase II metabolism or by intestinal microbials (115-117). HT, PA and HPP exhibit anti-proliferative and pro-apoptotic activities in colon cancer Caco2 and HT-29 cells. Whereas, PP and diHPP are only associated with apoptosis in HT-29 cells (78). HT-induced mitochondrial dysfunction and caspase-3 activation in CRC cells indicates an involvement of the intrinsic apoptosis pathway $(78,118)$.

Resveratrol. Trans-resveratrol, a natural stilbene present in wine and grapes, has been extensively investigated for its anti-inflammatory and anticancer activities (119). It has been reported to inhibit cell proliferation signaling pathways in a number of studies (120-123). In SW-620 and LoVo cells it has been reported to induce apoptosis via the mitochondria-dependent and -independent pathways via an upregulation of pro-apoptotic proteins and downregulation of anti-apoptotic proteins $(121,122)$.

Resveratrol has also been investigated in combination with etoposide in CRC cell lines (120-122). Synergistic effects have been observed on cell growth inhibition via downregulation of mitogen-activated protein kinase signaling pathways and an increase in apoptosis via activation of p53 (124-126). Additionally, a combination of resveratrol and grape seed extract has been reported to suppress Wnt/ $\beta$-catenin signaling and increase mitochondria-dependent apoptosis in in vitro and in vivo models (126).

Cumarins. Clausenidin is a natural pyranocoumarin obtained from Clausenidin excavate, which is a wild shrub of the Rutaceae family that is commonly used in Asian folk medicine. Clausenidin induces cell cycle arrest at the $G_{0} / G_{1}$ phase and apoptosis of HT29 cells, which is demonstrated by DNA fragmentation, MMP loss, increased expression of the pro-apoptotic protein Bax, cytochrome $c$ release, Apaf-1 gene expression and capsase- 9 and caspase- 3 activities. ROS generation also serves a role in Clausenidin-induced apoptosis (60). In summary, these events indicate an activation of the mitochondria-mediated intrinsic apoptosis pathway following treatment with Clausenidin.

\section{Alkaloids}

Piperine. Piperine is an amide alkaloid extracted from the fruits of black and long pepper plants (Piper nigrum Linn. and Piper longum Linn.) (45). Piperine arrests the cell cycle and inhibits CRC cell proliferation independent of p53 status $(45,65)$. Piperine induces apoptosis by inhibiting the cell survival PI3K/Akt signaling pathway and upregulating
ER stress response proteins, including inositol-requiring enzyme-1 $\alpha$, CHOP and binding immunoglobulin protein, which results in MMP loss, cytochrome $c$ release and PARP cleavage, which indicates a role of the intrinsic pathway in piperine-induced apoptosis (65).

Colchicine. Colchicine is an alkaloid isolated from Colchicum autumnale (meadow saffron) or Gloriosa superba (glory lily) (127). Colchicine is understood to halt cancer cell growth by its antimitotic activity (128). In colon cancer HT-29 cells, colchicine induces apoptosis via MMP loss, ROS production, caspase- 3 activation, upregulation of pro-apoptotic Bax, downregulation of anti-apoptotic $\mathrm{Bcl}-2$ and phosphorylation of p38, which indicates an involvement of p38-regulated intrinsic apoptosis pathway (61).

Xylopine. Xylopine is an aporphine alkaloid present in the stem of Xylopia laevigata (62); however, few studies have investigated this compound. Xylopine has been reported to arrest HCT116 cells at the $\mathrm{G}_{2} / \mathrm{M}$ phase and activate ROS-dependent intrinsic apoptosis independent of the p53 pathway (62).

Capsaicin. Capsaicin is a major pungent component in hot red pepper (79). Capsaicin induces apoptosis in colon cancer cells by arresting the cell cycle at the $G_{0} / G_{1}$ phase and is associated with an upregulation of the pro-apoptotic protein Bax in conjunction with PARP cleavage $(79,80)$. Capsaicin alters important cell cycle proteins, including decreasing the expression of cyclin D1 (129) and increasing the expression of p21 (80). Both p21 and Bax are downstream targets of p53 (80). Capsaicin also increases the expression of p53 and decreased apoptosis is observed in p53-knockdown cells, which indicates a key role of p53 in capsaicin-induced apoptosis (80).

Berberine. Berberine is an alkaloid present in numerous medicinal plants, including Hydrastis canadensis, Berberis aristata, Coptis chinensi, C. rhizome, C. japonica, phellodendron amurense and $P$. chinense Schneid, and other plant species used in traditional medicine (130). Berberine is known for its anticancer properties in several types of cancer, such as prostate cancer, neuroblastoma and osteosarcoma (131-133). In colon cancer cells, berberine induces apoptosis via caspase-dependent and -independent mechanisms $(130,134,135)$. In SW480 cells it induces cell cycle arrest at the $G_{0} / G_{1}$ phase and increases the expression of p21 (130). Furthermore, berberine induces the mitochondria-mediated apoptosis pathway by activating apoptosis-associated proteins, including caspase- 3 and caspase-9, induces the cleavage of PARP, upregulates the pro-apoptotic protein Bax and downregulates the anti-apoptotic protein Bcl-2 (135). Additionally, the activation of caspase- 8 by berberine in SW480 cells functions as a non-apoptotic inhibitor of angiogenesis by decreasing the release of vascular endothelial cell growth factor (135). In HCT-8 cells, berberine arrests the cell cycle at the $\mathrm{S}$ phase, and induces apoptosis via activation of the extrinsic and intrinsic apoptosis pathways via an upregulation of Fas, FasL, TNF $\alpha$, Bax and caspase-3, and a downregulation of Bcl-2 (83,136). 
Harmine. Harmine is a $\beta$-carboline alkaloid isolated from the seeds of Peganum harmala (137). Harmine has traditionally been used in medicinal preparations in the Middle East, Central Asia and South America (137). Harmine inhibits SW680 cell proliferation by arresting the cell cycle at the $\mathrm{S}$ and $\mathrm{G}_{2} / \mathrm{M}$ phases, and inhibiting Akt and ERK-mediated cell survival pathways (84). Additionally, harmine activates the mitochondria-mediated intrinsic apoptosis pathway via downregulation of the anti-apoptotic proteins Bcl-2, Mcl-1 and Bcl-xl, and upregulation of Bax (84).

\section{Evidence from clinical trials}

As aforementioned, a number of phytochemical groups have been demonstrated to induce apoptosis of CRC cells via multiple pathways in in vitro studies. However, clinical studies have been only performed with a limited number of phytochemicals. A phase I pilot study with resveratrol reported that it downregulates Wnt target gene expression in the normal colonic mucosa of patients with CRC, while it upregulates Wnt target genes, including myc and cyclin D1, in colon cancer (138). The mechanism of this increase remains to be completely elucidated and requires further investigation. The resveratrol-induced downregulation of the Wnt-associated genes in normal colonoic mucosa may exert a protective effect as Wnt and its downstream effectors are known to regulate processes involved in tumor initiation, tumor growth and metastasis (139). Another study that investigated the efficacy of resveratrol in patients with colorectal adenocarcinoma demonstrated a 5\% reduction in tumor cell proliferation, which indicates that daily oral doses of resveratrol at 0.5 or $1.0 \mathrm{~g}$ are sufficient to induce anti-carcinogenic effects (140). However, further clinical evaluation is required before it may be used as an alternative to non-steroidal anti-inflammatory agents and selective cyclooxygenase inhibitors in CRC chemoprevention (140).

Flavonols are understood to inhibit colorectal carcinogenesis via multiple mechanisms, including attenuation of inflammation (141-144). Elevated blood levels of IL-6 have also been observed in colorectal adenoma (145). In a 4-year, randomized, multi-center, nutritional intervention trial study it was demonstrated that a high flavonol intake results in a reduction of serum IL-6 level, which decreases the risk of colorectal adenoma recurrence (146).

An open non-randomized clinical study was performed with curcumin at dose of 4 or $2 \mathrm{~g}$ in patients with $\geq 8$ aberrant crypt foci (ACF) in a colonoscopic examination. Curcumin at a $4 \mathrm{~g}$ daily dose for 30 days reduced ACF by $40 \%$, while a $2 \mathrm{~g}$ dose exhibited no effect (147). Another clinical study demonstrated that administration of curcumin increased the body weight of patients with CRC, reduced serum TNF- $\alpha$ levels, upregulated p53 and increased DNA fragmentation in CRC cells (148).

\section{Conclusions and future directions}

Despite significant progress in the diagnosis and treatment of cancer, the incidence of CRC is increasing worldwide and is expected to rise by $60 \%$ by 2030 (1). Mutations or alterations in cancer are a major challenge for effective management. Due to the high incidence of resistance and adverse effects-associated with chemotherapeutic drugs, there is an urgent requirement to develop more effective therapeutics (149). Phytochemicals are known sources of various compounds that are currently used as chemotherapeutic drugs $(36,37)$. The current review summarized previously published studies regarding the effect of phytochemicals in CRC. To date, an extensive number of studies have been performed to identify molecular pathways involved in CRC and the effects of specific phytochemicals have been examined, primarily in preclinical trials. However, only a limited number have been performed in clinical settings. Therefore, for the majority of phytochemicals it is too early to conclude their anticancer properties. Further extensive research on phytochemicals is required to promote understanding and elucidate their molecular targets, drug interactions, ideal dosages, long-term safety and adverse effects.

\section{Acknowledgements}

Not applicable.

\section{Funding}

The present study was supported by JSPS KAKENHI (grant no. 17K09154).

\section{Availability of data and materials}

Not applicable.

\section{Authors' contributions}

KA and SFZ contributed to the planning and design of the study; KA drafted the manuscript; KA, SFZ, ZC, DZ, SAS and $\mathrm{HI}$ performed the critical revisions of the manuscript and reviewed the intellectual content.

\section{Ethics approval and consent to participate}

Not applicable.

\section{Patient consent for publication}

Not applicable.

\section{Competing interests}

The authors declare that they have no competing interests.

\section{References}

1. Arnold M, Sierra MS, Laversanne M, Soerjomataram I, Jemal A and Bray F: Global patterns and trends in colorectal cancer incidence and mortality. Gut 66: 683-691, 2017.

2. Siegel RL, Miller KD and Jemal A: Cancer statistics, 2018. CA Cancer J Clin 68: 7-30, 2018.

3. Zhang J, Wang TY and Niu XC: Increased plasma levels of pentraxin 3 are associated with poor prognosis of colorectal carcinoma patients. Tohoku J Exp Med 240: 39-46, 2016.

4. Ferlay J, Soerjomataram I, Dikshit R, Eser S, Mathers C, Rebelo M, Parkin DM, Forman D and Bray F: Cancer incidence and mortality worldwide: Sources, methods and major patterns in GLOBOCAN 2012. Int J Cancer 136: E359-E386, 2015. 
5. Terzić J, Grivennikov S, Karin E and Karin M: Inflammation and colon cancer. Gastroenterology 138: 2101-2114.e5, 2010.

6. Hafström L, Johansson H and Ahlberg J: Does diagnostic delay of colorectal cancer result in malpractice claims? A retrospective analysis of the Swedish board of malpractice from 1995-2008 Patient Saf Surg 6: 13, 2012.

7. Boland CR and Goel A: Microsatellite instability in colorectal cancer. Gastroenterology 138: 2073-2087.e3, 2010.

8. Lao VV and Grady WM: Epigenetics and colorectal cancer. Nat Rev Gastroenterol Hepatol 8: 686-700, 2011.

9. Pino MS and Chung DC: The chromosomal instability pathway in colon cancer. Gastroenterology 138: 2059-2072, 2010.

10. Naccarati A, Polakova V, Pardini B, Vodickova L, Hemminki K, Kumar R and Vodicka P: Mutations and polymorphisms in TP53 gene--an overview on the role in colorectal cancer. Mutagenesis 27: 211-218, 2012.

11. Xie Q, Wu MY, Zhang DX, Yang YM, Wang BS, Zhang J, $\mathrm{Xu}$ J, Zhong WD and Hu JN: Synergistic anticancer effect of exogenous wild-type p53 gene combined with 5-FU in human colon cancer resistant to 5-FU in vivo. World J Gastroenterol 22 7342-7352, 2016

12. Bykov VJN, Eriksson SE, Bianchi J and Wiman KG: Targeting mutant p53 for efficient cancer therapy. Nat Rev Cancer 18 89-102, 2018

13. Testa U, Pelosi E and Castelli G: Colorectal cancer: Genetic abnormalities, tumor progression, tumor heterogeneity, clonal evolution and tumor-initiating cells. Med Sci (Basel) 6: 1-113, 2018.

14. Wang S, Liu Z, Wang L and Zhang X: NF-kappaB signaling pathway, inflammation and colorectal cancer. Cell Mol Immunol 6: 327-334, 2009.

15. Vivanco I and Sawyers CL: The phosphatidylinositol 3-Kinase AKT pathway in human cancer. Nat Rev Cancer 2: 489-501, 2002.

16. PerSe M: Oxidative Stress in the Pathogenesis of Colorecta Cancer: Cause or Consequence? BioMed Res Int: 725710, 2013.

17. Pizzino $G$, Irrera $N$, Cucinotta $M$, Pallio $G$, Mannino $F$, Arcoraci V, Squadrito F, Altavilla D and Bitto A: Oxidative Stress: Harms and Benefits for Human Health. Oxid Med Cell Longev 2017: 8416763, 2017.

18. Cano CE, Gommeaux J, Pietri S, Culcasi M, Garcia S, Seux M, Barelier S, Vasseur S, Spoto RP, Pébusque MJ, et al: Tumor protein 53-induced nuclear protein 1 is a major mediator of p53 antioxidant function. Cancer Res 69: 219-226, 2009.

19. Flöter J, Kaymak I and Schulze A: Regulation of Metabolic Activity by p53. Metabolites 7: 1-18, 2017.

20. Kalo E, Kogan-Sakin I, Solomon H, Bar-Nathan E Shay M, Shetzer Y, Dekel E, Goldfinger N, Buganim Y, Stambolsky P, et al: Mutant p53R273H attenuates the expression of phase 2 detoxifying enzymes and promotes the survival of cells with high levels of reactive oxygen species. J Cell Sci 125 5578-5586, 2012

21. Liu J, Zhang C and Feng Z: Tumor suppressor p53 and its gain-of-function mutants in cancer. Acta Biochim Biophys Sin (Shanghai) 46: 170-179, 2014

22. Ahmed K, Tabuchi Y and Kondo T: Hyperthermia: An effective strategy to induce apoptosis in cancer cells. Apoptosis 20 $1411-1419,2015$

23. Cao K and Tait SWG: Apoptosis and Cancer: Force Awakens, Phantom Menace, or Both? Int Rev Cell Mol Biol 337: 135-152, 2018.

24. El-Khattouti A, Selimovic D, Haikel Y and Hassan M: Crosstalk between apoptosis and autophagy: Molecular mechanisms and therapeutic strategies in cancer. J Cell Death 6: 37-55, 2013

25. Chaitanya GV, Steven AJ and Babu PP: PARP-1 cleavage fragments: Signatures of cell-death proteases in neurodegeneration. Cell Commun Signal 8: 31, 2010.

26. Shiraishi H, Okamoto H, Yoshimura A and Yoshida H: ER stress-induced apoptosis and caspase-12 activation occurs downstream of mitochondrial apoptosis involving Apaf-1. J Cell Sci 119: 3958-3966, 2006.

27. Harding HP, Novoa I, Zhang Y, Zeng H, Wek R, Schapira M and Ron D: Regulated translation initiation controls stress-induced gene expression in mammalian cells. Mol Cell 6: 1099-1108, 2000

28. McCullough KD, Martindale JL, Klotz LO, Aw TY and Holbrook NJ: Gadd153 sensitizes cells to endoplasmic reticulum stress by down-regulating $\mathrm{Bcl} 2$ and perturbing the cellular redox state. Mol Cell Biol 21: 1249-1259, 2001.

29. Nakagawa T, Zhu H, Morishima N, Li E, Xu J, Yankner BA and Yuan J: Caspase-12 mediates endoplasmic-reticulum-specific apoptosis and cytotoxicity by amyloid-beta. Nature 403: 98-103, 2000 .
30. Rao RV, Castro-Obregon S, Frankowski H, Schuler M, Stoka V, del Rio G, Bredesen DE and Ellerby HM: Coupling endoplasmic reticulum stress to the cell death program. An Apaf-1-independent intrinsic pathway. J Biol Chem 277: 21836-21842, 2002.

31. Abraha AM and Ketema EB: Apoptotic pathways as a therapeutic target for colorectal cancer treatment. World J Gastrointest Onco 8: 583-591, 2016.

32. Stoian M, State N, Stoica V and Radulian G: Apoptosis in colorectal cancer. J Med Life 7: 160-164, 2014.

33. Zhang B, Fang C, Deng D and Xia L: Research progress on common adverse events caused by targeted therapy for colorectal cancer. Oncol Lett 16: 27-33, 2018. (review).

34. Lee JH, Khor TO, Shu L, Su ZY, Fuentes F and Kong AN: Dietary phytochemicals and cancer prevention: Nrf2 signaling, epigenetics, and cell death mechanisms in blocking cancer initiation and progression. Pharmacol Ther 137: 153-171, 2013.

35. Zaidi SF, Ahmed K, Saeed SA, Khan U and Sugiyama T: Can diet modulate helicobacter pylori associated gastric pathogenesis? An evidence-based analysis. Nutr Cancer 69: 979-989, 2017.

36. Newman DJ and Cragg GM: Natural products as sources of new drugs over the 30 years from 1981 to 2010. J Nat Prod 75: 311-335, 2012.

37. Nobili S, Lippi D, Witort E, Donnini M, Bausi L, Mini E and Capaccioli S: Natural compounds for cancer treatment and prevention. Pharmacol Res 59: 365-378, 2009.

38. Rejhová A, Opattová A, Cumová A, Slíva D and Vodička P. Natural compounds and combination therapy in colorectal cancer treatment. Eur J Med Chem 144: 582-594, 2018.

39. González-Vallinas M, González-Castejón M Rodríguez-Casado A and Ramírez de Molina A: Dietary phytochemicals in cancer prevention and therapy: A complementary approach with promising perspectives. Nutr Rev 71: 585-599, 2013.

40. Lee KW, Bode AM and Dong Z: Molecular targets of phytochemicals for cancer prevention. Nat Rev Cancer 11: 211-218, 2011.

41. Fung TT, Hu FB, Wu K, Chiuve SE, Fuchs $\mathrm{CS}$ and Giovannucci E: The mediterranean and dietary approaches to stop hypertension (DASH) diets and colorectal cancer. Am J Clin Nutr 92: 1429-1435, 2010.

42. Nomura AMY, Wilkens LR, Murphy SP, Hankin JH, Henderson BE, Pike MC and Kolonel LN: Association of vegetable, fruit, and grain intakes with colorectal cancer: The Multiethnic Cohort Study. Am J Clin Nutr 88: 730-737, 2008.

43. van Duijnhoven FJ, Bueno-De-Mesquita HB, Ferrari P, Jenab M, Boshuizen HC, Ros MM, Casagrande C, Tjønneland A, Olsen A, Overvad K, et al: Fruit, vegetables, and colorectal cancer risk: The European Prospective Investigation into Cancer and Nutrition. Am J Clin Nutr 89: 1441-1452, 2009.

44. Gunasekaran S, Venkatachalam $K$ and Namasivayam $N$ : p-Methoxycinnamic acid, an active phenylpropanoid induces mitochondrial mediated apoptosis in HCT-116 human colon adenocarcinoma cell line. Environ Toxicol Pharmacol 40: 966-974, 2015.

45. Yaffe PB, Doucette CD, Walsh M and Hoskin DW: Piperine impairs cell cycle progression and causes reactive oxygen species-dependent apoptosis in rectal cancer cells. Exp Mol Pathol 94: 109-114, 2013.

46. Banerjee $\mathrm{K}$ and Mandal M: Oxidative stress triggered by naturally occurring flavone apigenin results in senescence and chemotherapeutic effect in human colorectal cancer cells. Redox Biol 5: 153-162, 2015.

47. Watson JL, Hill R, Yaffe PB, Greenshields A, Walsh M, Lee PW, Giacomantonio CA and Hoskin DW: Curcumin causes superoxide anion production and p53-independent apoptosis in human colon cancer cells. Cancer Lett 297: 1-8, 2010.

48. Singh N, Shrivastav A and Sharma RK: Curcumin induces caspase and calpain-dependent apoptosis in HT29 human colon cancer cells. Mol Med Rep 2: 627-631, 2009.

49. Liu B, Yuan B, Zhang L, Mu W and Wang C: ROS/p38/p53/Puma signaling pathway is involved in emodin-induced apoptosis of human colorectal cancer cells. Int J Clin Exp Med 8: $15413-15422,2015$.

50. Raja SB, Rajendiran V, Kasinathan NK, P A, Venkatabalasubramanian S, Murali MR, Devaraj $\mathrm{H}$ and Devaraj SN: Differential cytotoxic activity of Quercetin on colonic cancer cells depends on ROS generation through COX-2 expression. Food Chem Toxicol 106 (Pt A): 92-106, 2017. 
51. Kwon O, Soung NK, Thimmegowda NR, Jeong SJ, Jang JH, Moon DO, Chung JK, Lee KS, Kwon YT, Erikson RL, et al: Patulin induces colorectal cancer cells apoptosis through EGR-1 dependent ATF3 up-regulation. Cell Signal 24: 943-950, 2012.

52. Miki H, Uehara N, Kimura A, Sasaki T, Yuri T, Yoshizawa K and Tsubura A: Resveratrol induces apoptosis via ROS-triggered autophagy in human colon cancer cells. Int J Oncol 40: 1020-1028, 2012.

53. Han MH, Kim GY, Yoo YH and Choi YH: Sanguinarine induces apoptosis in human colorectal cancer HCT-116 cells through ROS-mediated Egr-1 activation and mitochondrial dysfunction. Toxicol Lett 220: 157-166, 2013.

54. Li M, Song LH, Yue GG, Lee JKM, Zhao LM, Li L, Zhou X, Tsui SK, Ng SS, Fung KP, et al: Bigelovin triggered apoptosis in colorectal cancer in vitro and in vivo via upregulating death receptor 5 and reactive oxidative species. Sci Rep 7: 42176-42188, 2017.

55. Shang HS, Liu JY, Lu HF, Chiang HS, Lin CH, Chen A, Lin YF, Chung JG, Ng SS, et al: Casticin induced apoptotic cell death and altered associated gene expression in human colon cancer colo 205 cells. Environ Toxicol 32: 2041-2052, 2017.

56. Sithara T, Arun KB, Syama HP, Reshmitha TR and Nisha P: Morin inhibits proliferation of sw 480 colorectal cancer cells by inducing apoptosis mediated by reactive oxygen species formation and uncoupling of Warburg effect. Front Pharmacol 8: 640, 2017.

57. Khamphio M, Barusrux S and Weerapreeyakul N: Sesamo induces mitochondrial apoptosis pathway in HCT116 human colon cancer cells via pro-oxidant effect. Life Sci 158: 46-56, 2016.

58. Subramanian AP, Jaganathan SK, Mandal M, Supriyanto E and Muhamad II: Gallic acid induced apoptotic events in HCT-15 colon cancer cells. World J Gastroenterol 22: 3952-3961, 2016.

59. Lim JH, Lee YM, Park SR, Kim DH and Lim BO: Anticancer activity of hispidin via reactive oxygen species-mediated apoptosis in colon cancer cells. Anticancer Res 34: 4087-4093, 2014.

60. Waziri PM, Abdullah R, Yeap SK, Omar AR, Kassim NK, Malami I, How CW, Etti IC and Abu ML: Clausenidin induces caspase-dependent apoptosis in colon cancer. BMC Complement Altern Med 16: 256, 2016.

61. Huang $\mathrm{Z}, \mathrm{Xu} \mathrm{Y}$ and Peng $\mathrm{W}$ : Colchicine induces apoptosis in HT-29 human colon cancer cells via the AKT and c-Jun N-terminal kinase signaling pathways. Mol Med Rep 12: 5939-5944, 2015

62. Santos LS, Silva VR, Menezes LRA, Soares MBP, Costa EV and Bezerra DP: Xylopine induces oxidative stress and causes $\mathrm{G} 2 / \mathrm{M}$ phase arrest, triggering caspase-mediated apoptosis by 53 -independent pathway in HCT116 cells. Oxid Med Cell Longev 2017: 7126872, 2017.

63. Sun G, Zheng Z, Lee MH, Xu Y, Kang S, Dong Z, Wang M, Gu Z, Li H and Chen W: Chemoprevention of Colorectal Cancer by Artocarpin, a Dietary Phytochemical from Artocarpus heterophyllus. J Agric Food Chem 65: 3474-3480, 2017

64. Kaur M, Velmurugan B, Tyagi A, Deep G, Katiyar S, Agarwal C and Agarwal R: Silibinin suppresses growth and induces apoptotic death of human colorectal carcinoma LoVo cells in culture and tumor xenograft. Mol Cancer Ther 8: 2366-2374, 2009.

65. Yaffe PB, Power Coombs MR, Doucette CD, Walsh M and Hoskin DW: Piperine, an alkaloid from black pepper, inhibits growth of human colon cancer cells via G1 arrest and apoptosis triggered by endoplasmic reticulum stress. Mol Carcinog 54: 1070-1085, 2015

66. Yang $\mathrm{D}$, Zhang $X$, Zhang $\mathrm{W}$ and Rengarajan T: Vicenin-2 inhibits Wnt/3-catenin signaling and induces apoptosis in HT-29 human colon cancer cell line. Drug Des Devel Ther 12: 1303-1310, 2018.

67. Dasiram JD, Ganesan R, Kannan J, Kotteeswaran V and Sivalingam N: Curcumin inhibits growth potential by G1 cell cycle arrest and induces apoptosis in p53-mutated COLO 320DM human colon adenocarcinoma cells. Biomed Pharmacother 86 373-380, 2017.

68. Agarwal A, Kasinathan A, Ganesan R, Balasubramanian A Bhaskaran J, Suresh S, Srinivasan R, Aravind KB and Sivalingam N: Curcumin induces apoptosis and cell cycle arrest via the activation of reactive oxygen species-independent mitochondrial apoptotic pathway in Smad4 and p53 mutated colon adenocarcinoma HT29 cells. Nutr Res 51: 67-81, 2018.

69. Liu B, Zhou Z, Zhou W, Liu J, Zhang Q, Xia J, Liu J, Chen N, $\mathrm{Li} \mathrm{M}$ and Zhu R: Resveratrol inhibits proliferation in human colorectal carcinoma cells by inducing G1/S-phase cell cycle arrest and apoptosis through caspase/cyclin-CDK pathways. Mol Med Rep 10: 1697-1702, 2014.
70. Eldhose B, Gunawan M, Rahman M, Latha MS and Notario V: Plumbagin reduces human colon cancer cell survival by inducing cell cycle arrest and mitochondria-mediated apoptosis. Int J Oncol 45: 1913-1920, 2014.

71. Kim HJ, Park JH and Kim JK: Cucurbitacin-I, a natural cell-permeable triterpenoid isolated from Cucurbitaceae, exerts potent anticancer effect in colon cancer. Chem Biol Interact 219: $1-8,2014$.

72. Amin A, Bajbouj K, Koch A, Gandesiri M and Schneider-Stock R: Defective autophagosome formation in p53-null colorectal cancer reinforces crocin-induced apoptosis. Int J Mol Sci 16: 1544-1561, 2015.

73. Li CY, Huang WF, Wang QL, Wang F, Cai E, Hu B, Du JC, Wang J, Chen R, Cai XJ, et al: Crocetin induces cytotoxicity in colon cancer cells via p53-independent mechanisms. Asian Pac J Cancer Prev 13: 3757-3761, 2012.

74. 74. Lee YJ, Kang YR, Lee SY, Jin Y, Han DC and Kwon BM: Ginkgetin induces G2-phase arrest in HCT116 colon cancer cells through the modulation of b-Myb and miRNA34a expression. Int J Oncol 51: 1331-1342, 2017.

75. Radhakrishnan EK, Bava SV, Narayanan SS, Nath LR, Thulasidasan AKT, Soniya EV and Anto RJ: [6]-Gingerol induces caspase-dependent apoptosis and prevents PMA-induced proliferation in colon cancer cells by inhibiting MAPK/AP-1 signaling. PLoS One 9: e104401, 2014

76. Yang L, Liu Y, Wang M, Qian Y, Dong X, Gu H, Wang H, Guo S and Hisamitsu T: Quercetin-induced apoptosis of HT-29 colon cancer cells via inhibition of the Akt-CSN6-Myc signaling axis. Mol Med Rep 14: 4559-4566, 2016.

77. Cho HJ and Park JHY: Kaempferol induces cell cycle arrest in HT-29 human colon cancer cells. J Cancer Prev 18: 257-263, 2013.

78. López de Las Hazas MC, Piñol C, Macià A and Motilva MJ: Hydroxytyrosol and the colonic metabolites derived from virgin olive oil intake induce cell cycle arrest and apoptosis in colon cancer cells. J Agric Food Chem 65: 6467-6476, 2017.

79. Lee SH and Clark R: Anti-Tumorigenic Effects of Capsaicin in Colon Cancer. J Food Chem Nanotechnol 2: 162-167, 2016.

80. Jin J, Lin G, Huang H, Xu D, Yu H, Ma X, Zhu L, Ma D and Jiang H: Capsaicin mediates cell cycle arrest and apoptosis in human colon cancer cells via stabilizing and activating p53. Int J Biol Sci 10: 285-295, 2014

81. Chidambara Murthy KN, Jayaprakasha GK and Patil BS: The natural alkaloid berberine targets multiple pathways to induce cell death in cultured human colon cancer cells. Eur J Pharmacol 688: 14-21, 2012.

82. Xu LN, Lu BN, Hu MM, Xu YW, Han X, Qi Y and Peng JY: Mechanisms involved in the cytotoxic effects of berberine on human colon cancer HCT-8 cells. Biocell 36: 113-120, 2012.

83. Cai Y, Xia Q, Luo R, Huang P, Sun Y, Shi Y and Jiang W: Berberine inhibits the growth of human colorectal adenocarcinoma in vitro and in vivo. $\mathrm{J}$ Nat Med 68: 53-62, 2014.

84. Liu J, Li Q, Liu Z, Lin L, Zhang X, Cao M and Jiang J: Harmine induces cell cycle arrest and mitochondrial pathway-mediated cellular apoptosis in SW620 cells via inhibition of the Akt and ERK signaling pathways. Oncol Rep 35: 3363-3370, 2016.

85. Tailor D and Singh RP: Dietary and non-dietary phytochemicals in cancer control. In: Nutrition, Diet and Cancer. Shankar S and Shrivastava RK (eds). Springer, New York, pp585-622, 2012.

86. Milani A, Basirnejad M, Shahbazi S and Bolhassani A: Carotenoids: Biochemistry, pharmacology and treatment. Br J Pharmacol 174: 1290-1324, 2017.

87. Gutheil WG, Reed G, Ray A, Anant S and Dhar A: Crocetin: An agent derived from saffron for prevention and therapy for cancer. Curr Pharm Biotechnol 13: 173-179, 2012.

88. Ray P, Guha D, Chakraborty J, Banerjee S, Adhikary A Chakraborty S, Das T and Sa G: Crocetin exploits p53-induced death domain (PIDD) and FAS-associated death domain (FADD) proteins to induce apoptosis in colorectal cancer. Sci Rep 6: 32979-32989, 2016.

89. Chakraborty D, Bishayee K, Ghosh S, Biswas R, Mandal SK and Khuda-Bukhsh AR: [6]-Gingerol induces caspase 3 dependent apoptosis and autophagy in cancer cells: drug-DNA interaction and expression of certain signal genes in HeLa cells. Eur J Pharmacol 694: 20-29, 2012.

90.Ju SA, Park SM, Lee YS, Bae JH, Yu R, An WG, Suh JH and Kim BS: Administration of 6-gingerol greatly enhances the number of tumor-infiltrating lymphocytes in murine tumors. Int J Cancer 130: 2618-2628, 2012.

91.Panche AN, Diwan AD and Chandra SR: Flavonoids: An overview. J Nutr Sci 5: e47, 2016. 
92. Kim HJ, Kim SK, Kim BS, Lee SH, Park YS, Park BK, Kim SJ, Kim J, Choi C, Kim JS, et al: Apoptotic effect of quercetin on HT-29 colon cancer cells via the AMPK signaling pathway. J Agric Food Chem 58: 8643-8650, 2010.

93. Refolo MG, D'Alessandro R, Malerba N, Laezza C, Bifulco M, Messa C, Caruso MG, Notarnicola $M$ and Tutino V: Anti-proliferative and pro apoptotic effects of flavonoid quercetin are mediated by CB1 receptor in human colon cancer cell lines. J Cell Physiol 230: 2973-2980, 2015.

94.Zhang XA, Zhang S, Yin Q and Zhang J: Quercetin induces human colon cancer cells apoptosis by inhibiting the nuclear factor-kappa B Pathway. Pharmacogn Mag 11: 404-409, 2015.

95. Liu Y, Lang T, Jin B, Chen F, Zhang Y, Beuerman RW, Zhou L and Zhang Z: Luteolin inhibits colorectal cancer cell epithelial-to-mesenchymal transition by suppressing CREB1 expression revealed by comparative proteomics study. J Proteomics 161: 1-10, 2017.

96. Kang KA, Piao MJ, Ryu YS, Hyun YJ, Park JE, Shilnikova K, Zhen AX, Kang HK, Koh YS, Jeong YJ, et al: Luteolin induces apoptotic cell death via antioxidant activity in human colon cancer cells. Int J Oncol 51: 1169-1178, 2017.

97. Yang N,Zhao Y, Wang Z, Liu Y and Zhang Y: Scutellarin suppresses growth and causes apoptosis of human colorectal cancer cells by regulating the p53 pathway. Mol Med Rep 15: 929-935, 2017.

98.Lee JH, Choi YJ, Park SH and Nam MJ: Potential role of nucleoside diphosphate kinase in myricetin-induced selective apoptosis in colon cancer HCT-15 cells. Food Chem Toxicol 116 (Pt B): 315-322, 2018

99. Seydi E, Rasekh HR, Salimi A, Mohsenifar Z and Pourahmad J: Myricetin selectively induces apoptosis on cancerous hepatocytes by directly targeting their mitochondria. Basic Clin Pharmacol Toxicol 119: 249-258, 2016.

100. Phillips PA, Sangwan V, Borja-Cacho D, Dudeja V, Vickers SM and Saluja AK: Myricetin induces pancreatic cancer cell death via the induction of apoptosis and inhibition of the phosphatidylinositol 3-kinase (PI3K) signaling pathway. Cancer Lett 308: 181-188, 2011.

101. Xu M, Wang S, Song YU, Yao J, Huang K and Zhu X: Apigenin suppresses colorectal cancer cell proliferation, migration and invasion via inhibition of the $\mathrm{Wnt} / \beta$-catenin signaling pathway. Oncol Lett 11: 3075-3080, 2016.

102.Zhou Z, Tang M, Liu Y, Zhang Z, Lu R and Lu J: Apigenin inhibits cell proliferation, migration, and invasion by targeting Akt in the A549 human lung cancer cell line. Anticancer Drugs 28: 446-456, 2017.

103. Liu X, Li L, Lv L, Chen D, Shen L and Xie Z: Apigenin inhibits the proliferation and invasion of osteosarcoma cells by suppressing the Wnt $/ \beta$-catenin signaling pathway. Oncol Rep 34: 1035-1041, 2015 .

104. Maeda Y, Takahashi H, Nakai N, Yanagita T, Ando N, Okubo T, Saito K, Shiga K, Hirokawa T, Hara M, et al: Apigenin induces apoptosis by suppressing Bcl-xl and Mcl-1 simultaneously via signal transducer and activator of transcription 3 signaling in colon cancer. Int J Oncol 52: 1661-1673, 2018.

105. Bobe G, Sansbury LB, Albert PS, Cross AJ, Kahle L, Ashby J, Slattery ML, Caan B, Paskett E, Iber F, et al: Dietary flavonoids and colorectal adenoma recurrence in the Polyp Prevention Trial. Cancer Epidemiol Biomarkers Prev 17: 1344-1353, 2008.

106. Lee HS, Cho HJ, Yu R, Lee KW, Chun HS and Park JHY: Mechanisms underlying apoptosis-inducing effects of Kaempferol in HT-29 human colon cancer cells. Int J Mol Sci 15: 2722-2737, 2014.

107. Tong W, Wang Q, Sun D and Suo J: Curcumin suppresses colon cancer cell invasion via AMPK-induced inhibition of NF- $x \mathrm{~B}$, UPA activator and MMP9. Oncol Lett 12: 4139-4146, 2016

108. Yang X, Li Z, Wu Q, Chen S, Yi C and Gong C: TRAIL and curcumin codelivery nanoparticles enhance TRAIL-induced apoptosis through upregulation of death receptors. Drug Deliv 24: 1526-1536, 2017 .

109. Shakibaei M, Kraehe P, Popper B, Shayan P, Goel A and Buhrmann C: Curcumin potentiates antitumor activity of 5-fluorouracil in a 3D alginate tumor microenvironment of colorectal cancer. BMC Cancer 15: 250, 2015.

110. Shakibaei M, Mobasheri A, Lueders C, Busch F, Shayan P and Goel A: Curcumin enhances the effect of chemotherapy against colorectal cancer cells by inhibition of NF- $x \mathrm{~B}$ and Src protein kinase signaling pathways. PLoS One 8: e57218, 2013.

111. Liu Z, Ren B, Wang Y, Zou C, Qiao Q, Diao Z, Mi Y, Zhu D and Liu X: Sesamol induces human hepatocellular carcinoma cells apoptosis by impairing mitochondrial function and suppressing autophagy. Sci Rep 7: 45728, 2017.
112. Bhardwaj R, Sanyal SN, Vaiphei K, Kakkar V, Deol PK, Kaur IP and Kaur T: Sesamol induces apoptosis by altering expression of bcl-2 and bax proteins and modifies skin tumor development in Balb/c mice. Anticancer Agents Med Chem 17: 726-733, 2017.

113. Daglia M, Di Lorenzo A, Nabavi SF, Talas ZS and Nabavi SM Polyphenols: well beyond the antioxidant capacity: gallic acid and related compounds as neuroprotective agents: you are what you eat! Curr Pharm Biotechnol 15: 362-372, 2014.

114. Yang $C$, Xie X, Tang H, Dong X, Zhang X and Huang F: Transcriptome analysis reveals GA induced apoptosis in HCT116 human colon cancer cells through calcium and p53 signal pathways. RSC Advances 8: 12449-12458, 2018.

115. Rubió L, Macià A, Valls RM, Pedret A, Romero MP, Solà R and Motilva MJ: A new hydroxytyrosol metabolite identified in human plasma: Hydroxytyrosol acetate sulphate. Food Chem 134: 1132-1136, 2012

116. de Las Hazas MCL, Motilva MJ, Piñol $\mathrm{C}$ and Macià $\mathrm{A}$ : Application of dried blood spot cards to determine olive oil phenols (hydroxytyrosol metabolites) in human blood. Talanta 159: 189-193, 2016

117. Mosele JI, Martín-Peláez S, Macià A, Farràs M, Valls RM, Catalán Ú and Motilva MJ: Faecal microbial metabolism of olive oil phenolic compounds: In vitro and in vivo approaches. Mol Nutr Food Res 58: 1809-1819, 2014.

118. Sun L, Luo C and Liu J: Hydroxytyrosol induces apoptosis in human colon cancer cells through ROS generation. Food Funct 5: 1909-1914, 2014.

119. Bertelli AA, Ferrara F, Diana G, Fulgenzi A, Corsi M, Ponti W, Ferrero ME and Bertelli A: Resveratrol, a natural stilbene in grapes and wine, enhances intraphagocytosis in human promonocytes: A co-factor in antiinflammatory and anticancer chemopreventive activity. Int J Tissue React 21: 93-104, 1999.

120. Buhrmann C, Shayan P, Popper B, Goel A and Shakibaei M: Sirt1 is required for resveratrolmediated chemopreventive effects in colorectal cancer cells. Nutrients 8: 145, 2016.

121. Chen H, Jin ZL and Xu H: MEK/ERK signaling pathway in apoptosis of SW620 cell line and inhibition effect of resveratrol. Asian Pac J Trop Med 9: 49-53, 2016.

122. Yuan SX, Wang DX, Wu QX, Ren CM, Li Y, Chen QZ, Zeng YH, Shao Y, Yang JQ, Bai Y, et al: BMP9/p38 MAPK is essential for the antiproliferative effect of resveratrol on human colon cancer. Oncol Rep 35: 939-947, 2016.

123. Saud SM, Li W, Morris NL, Matter MS, Colburn NH, Kim YS and Young MR: Resveratrol prevents tumorigenesis in mouse model of Kras activated sporadic colorectal cancer by suppressing oncogenic Kras expression. Carcinogenesis 35: 2778-2786, 2014.

124. De Maria S, Scognamiglio I, Lombardi A, Amodio N, Caraglia M, Cartenì M, Ravagnan $G$ and Stiuso P: Polydatin, a natural precursor of resveratrol, induces cell cycle arrest and differentiation of human colorectal Caco-2 cell. J Transl Med 11: 264, 2013.

125.Kumazaki M, Noguchi S, Yasui Y, Iwasaki J, Shinohara H, Yamada $\mathrm{N}$ and Akao Y: Anti-cancer effects of naturally occurring compounds through modulation of signal transduction and miRNA expression in human colon cancer cells. J Nutr Biochem 24: 1849-1858, 2013.

126. Reddivari L, Charepalli V, Radhakrishnan S, Vadde R, Elias RJ, Lambert JD and Vanamala JKP: Grape compounds suppress colon cancer stem cells in vitro and in a rodent model of colon carcinogenesis. BMC Complement Altern Med 16: 278, 2016.

127. Sivakumar G: Colchicine semisynthetics: Chemotherapeutics for cancer? Curr Med Chem 20: 892-898, 2013.

128. Risinger AL, Giles FJ and Mooberry SL: Microtubule dynamics as a target in oncology. Cancer Treat Rev 35: 255-261, 2009.

129.Lee SH, Richardson RL, Dashwood RH and Baek SJ: Capsaicin represses transcriptional activity of $\beta$-catenin in human colorectal cancer cells. J Nutr Biochem 23: 646-655, 2012.

130. Guamán Ortiz LM, Tillhon M, Parks M, Dutto I, Prosperi E Savio M, Arcamone AG, Buzzetti F, Lombardi P and Scovassi AI: Multiple effects of berberine derivatives on colon cancer cells. BioMed Res Int 2014: 924585, 2014.

131. Wang Y, Liu Q, Liu Z, Li B, Sun Z, Zhou H, Zhang X, Gong Y and Shao C: Berberine, a genotoxic alkaloid, induces ATM-Chk1 mediated G2 arrest in prostate cancer cells. Mutat Res 734: 20-29, 2012.

132. Li J, Gu L, Zhang H, Liu T, Tian D, Zhou M and Zhou S: Berberine represses DAXX gene transcription and induces cancer cell apoptosis. Lab Invest 93: 354-364, 2013. 
133. Yan K, Zhang C, Feng J, Hou L, Yan L, Zhou Z, Liu Z, Liu C, Fan Y, Zheng B, et al: Induction of G1 cell cycle arrest and apoptosis by berberine in bladder cancer cells. Eur $\mathbf{J}$ Pharmacol 661: 1-7, 2011.

134. Tillhon M, Guamán Ortiz LM, Lombardi P and Scovassi AI: Berberine: New perspectives for old remedies. Biochem Pharmacol 84: 1260-1267, 2012.

135. Wang L, Liu L, Shi Y, Cao H, Chaturvedi R, Calcutt MW, $\mathrm{Hu}$ T, Ren X, Wilson KT, Polk DB, et al: Berberine induces caspase-independent cell death in colon tumor cells through activation of apoptosis-inducing factor. PLoS One 7: e36418, 2012.

136. Xu LN, Lu BN, Hu MM, Xu YW, Han X, Qi Y and Peng JY: Mechanisms involved in the cytotoxic effects of berberine on human colon cancer HCT-8 cells. Biocell36: 113-20, 2012

137.Patel K, Gadewar M, Tripathi R, Prasad SK and Patel DK: A review on medicinal importance, pharmacological activity and bioanalytical aspects of beta-carboline alkaloid 'Harmine'. Asian Pac J Trop Biomed 2: 660-664, 2012.

138. Nguyen AV, Martinez M, Stamos MJ, Moyer MP, Planutis K, Hope C and Holcombe RF: Results of a phase I pilot clinical trial examining the effect of plant-derived resveratrol and grape powder on Wnt pathway target gene expression in colonic mucosa and colon cancer. Cancer Manag Res 1: 25-37, 2009.

139. Anastas JN and Moon RT: WNT signalling pathways as therapeutic targets in cancer. Nat Rev Cancer 13: 11-26, 2013.

140. Patel KR, Brown VA, Jones DJ, Britton RG, Hemingway D, Miller AS, West KP, Booth TD, Perloff M, Crowell JA, et al: Clinical pharmacology of resveratrol and its metabolites in colorectal cancer patients. Cancer Res 70: 7392-7399, 2010.

141. Ferguson LR and Philpott M: Cancer prevention by dietary bioactive components that target the immune response. Curr Cancer Drug Targets 7: 459-464, 2007.

142. Camuesco D, Comalada M, Rodríguez-Cabezas ME, Nieto A, Lorente MD, Concha A, Zarzuelo A and Gálvez J: The intestinal anti-inflammatory effect of quercitrin is associated with an inhibition in iNOS expression. Br J Pharmacol 143: 908-918, 2004.
143. Kwon KH, Murakami A, Tanaka T and Ohigashi H: Dietary rutin, but not its aglycone quercetin, ameliorates dextran sulfate sodium-induced experimental colitis in mice: Attenuation of pro-inflammatory gene expression. Biochem Pharmacol 69: 395-406, 2005.

144. Camuesco D, Comalada M, Concha A, Nieto A, Sierra S, Xaus J, Zarzuelo A and Gálvez J: Intestinal anti-inflammatory activity of combined quercitrin and dietary olive oil supplemented with fish oil, rich in EPA and DHA (n-3) polyunsaturated fatty acids, in rats with DSS-induced colitis. Clin Nutr 25: 466-476, 2006.

145. Kim S, Keku TO, Martin C, Galanko J, Woosley JT, Schroeder JC, Satia JA, Halabi S and Sandler RS: Circulating levels of inflammatory cytokines and risk of colorectal adenomas. Cancer Res 68: 323-328, 2008.

146. Bobe G, Albert PS, Sansbury LB, Lanza E, Schatzkin A, Colburn NH and Cross AJ: Interleukin-6 as a potential indicator for prevention of high-risk adenoma recurrence by dietary flavonols in the polyp prevention trial. Cancer Prev Res (Phila) 3 : 764-775, 2010.

147. Carroll RE, Benya RV, Turgeon DK, Vareed S, Neuman M, Rodriguez L, Kakarala M, Carpenter PM, McLaren C, Meyskens FL Jr, et al: Phase IIa clinical trial of curcumin for the prevention of colorectal neoplasia. Cancer Prev Res (Phila) 4: 354-364, 2011

148. He ZY, Shi CB, Wen H, Li FL, Wang BL and Wang J: Upregulation of p53 expression in patients with colorectal cancer by administration of curcumin. Cancer Invest 29: 208-213, 2011.

149. Chakraborty $\mathrm{S}$ and Rahman T: The difficulties in cancer treatment. Ecancermedicalscience 6: ed16, 2012.

This work is licensed under a Creative Commons

Attribution-NonCommercial-NoDerivatives

4.0

International (CC BY-NC-ND 4.0) License. 